\title{
Perlindungan Hukum Perjanjian bagi Hasil Petani Garam di Kabupaten Pamekasan dalam Perspektif Hukum Islam dan Hukum Perdata
}

\author{
Achmad Badarus Syamsi \\ Galuh Widitya Qomaro \\ Fakultas Keislaman Universitas Trunojoyo Madura \\ Jl. Raya Telang PO BOX 2 Kamal Bangkalan \\ Email:bsyams85@gmail.com,gwiditya@gmail.com
}

$\begin{array}{llll}\text { Submit } & : 5 \text { Februari } 2020 & \text { Diterima } & : \text { 13 Mei } 2020 \\ \text { Revisi } & : 11 \text { April } 2020 & \text { Terbit } & : \text { 03 Juni 2020 }\end{array}$

\begin{abstract}
Abstrak: Fungsi ijab kabul dalam suatu perjanjian (akad) adalah sebagai sebuah persetujuan kedua belah pihak atas hak dan kewajiban masing-masing, sehingga apabila ada pihak yang haknya tidak terpenuhi ia dapat merasa terlindungi dan menuntut hak-haknya tersebut. Oleh karena itulah sudah sepatutnya suatu ijab kabul atas suatu akad harus dilaksanakan sebaik mungkin yang dapat menjamin hak kedua belah pihak. Pulau Madura merupakan ladang garam terbaik di Indonesia, sehingga banyak kontrak yang dilakukan antara petani dengan pemilik lahan garam. Artikel ini membahas tentang pola bagi hasil antara petani dan pemilik lahan garam di Kabupaten Pamekasan dengan menggunakan skema setengah dan sepertiga, seperlima dan dua perlima. Pola-pola bagi hasil tersebut mempunyai hak dan kewajiban yang berbeda. Perbedaannya adalah kewajiban yang lebih besar kepada yang memperoleh setengah. Penulis menemukan bahwa pola perjanjian bagi hasil yang dilakukan oleh petani penggarap dan pemilik lahan garam di Kabupaten Pamekasan menurut Hukum Perjanjian dan Hukum Islam belum memenuhi prinsip dasar dalam sebuah perjanjian, karena perjanjian yang dilakukan hanya secara lisan dan tidak adanya saksi, sehingga berdampak pada minimnya perlindungan hukum bagi petani penggarap dan tidak adanya saksi menyebabkan tidak tegasnya batasan pelaksanaan akad.
\end{abstract}

Kata Kunci: Perjanjian, Pola Bagi Hasil, Petani Garam, Perlindungan, Pamekasan

Abstract: The function of approval in an agreement (contract) is as a statement between the two parties on their respective rights and obligations, so that if there are parties whose rights are not fulfilled, they can feel protected and demand these rights. Therefore, it is appropriate that an agreement on a contract must be carried out properly so that it can guarantee the rights of both parties. Madura Island is the best salt field in Indonesia, so there are many contracts between farmers and salt land owners. This article discusses the pattern of revenue sharing between farmers and salt land owners in Pamekasan Regency using the schemes of a half to a third and one fifth to two fifths. These revenue sharing patterns have different rights and obligations. The difference is a bigger obligation to those who get half. The author found that the pattern of production sharing agreements made by farmers and salt land owners in Pamekasan Regency according to the Agreement Law and Islamic Law did not meet the basic principles of agreement, because the agreement was made only verbally and there were no witnesses, so that it had an impact on the lack of protection for farmers and the absence of witnesses causes no clarity on the boundaries of the contract.

Keywords: Agreement, Profit-Sharing Pattern, Salt Farmers, Protection, Pamekasan 


\section{Pendahuluan}

Pulau Madura dikenal atau popular dengan sebutan pulau garam. Hal itu dapat dilihat dari persentase secara nasional, bahwa produksi garam di pulau Madura memang sangat besar, yaitu bisa mencapai 60\% dari total produksi dari seluruh Nusantara. Pulau Madura mempunyai luas lahan 11.695 hektare. Akan tetapi, dibandingkan keseluruhan luas lahannya, angka tersebut terbilang sangat kecil, karena jika dipersentase hanya 2,26\% lahan di Madura yang sebenarnya digarap menjadi kawasan pertanian garam. Menurut Sekretaris Jenderal Asosiasi Petani Garam Republik Indonesia (APGRI), Faisal Baidawi, luas wilayah pertanian garam rakyat di Indonesia berkisar 23.000 - 24.000 hektare. Jika merujuk ke data asosiasi ini, luas lahan produksi garam di Madura sekurang-kurangnya sudah mencapai 50\% dari total luas lahan garam di seluruh Nusantara. ${ }^{1}$

Musim di Madura memang dikenal kering lebih panjang, tidak memiliki banyak sungai dan sumber air tawar. Secara geografis daratan Madura relatif datar di sisi selatan, dengan dataran tinggi di tengah, dan pantai utara yang berbeda ketinggian. Suhu rata-rata Madura 26,9 derajat celsius, dengan kemarau panjang antara 4 sampai 5 bulan (rata-rata bulan kering 2 sampai 4 bulan). Meski garam hanya dihasilkan di sepanjang pantai selatan Madura. Sedikitnya sungai dan muara membuat kawasan selatan memiliki air laut berkadar garam tinggi. Proses pembuatan garam rakyat di Madura kerap disebut cara Madurese atau cara orang Madura, yaitu pembuatan garam dengan cara kristalisasi air laut secara total, kemudian pengambilan garam dimulai dari lapisan paling bawah sampai permukaan. ${ }^{2}$

Terdapat empat kabupaten di Madura, yaitu Bangkalan, Sampang, Pamekasan dan Sumenep. Dari keempat kabupaten yang ada di pulau Madura, kabupaten Pamekasan merupakan kabupaten yang kondisi ekonomi masyarakatnya paling baik. Hal itu dapat dilihat dari data bahwa kabupaten Pamekasan merupakan kabupaten yang memiliki jumlah warga miskin paling sedikit dibandingkan dengan tiga kabupaten lainnya. Berikut adalah datanya kabupaten Sampang dengan jumlah penduduk miskin sebanyak 227.800 orang, Sumenep jumlah penduduk miskin 216.140 orang Bangkalan sebanyak 205.710 orang. Sementara Pamekasan jumlah warga miskinnya sebanyak 142.320 orang. ${ }^{3}$ Hal tersebut menunjukan juga bahwa kondisi ekonomi petani garam kabupaten Pamekasan diatas tiga kabupaten lainnya.

Kabupaten Pamekasan memiliki tiga kawasan lumbung garam yang sudah terkenal sedari dulu, yakni di Kecamatan Tlanakan, Pademawu, dan Galis. Dari ketiganya, didapati total lahan garam seluas 914 Ha, dengan rincian Kecamatan Tlanakan 9,6 Ha, kecamatan Pademawu 446 Ha dan Kecamatan Galis 457,9 Ha. Meskipun terlihat besar, nyatanya angka ini hanyalah 1,24\% dari total luas wilayah Pamekasan. Terdapat 1.463 petani garam dari ketiga kecamatan yang menjadi pusat penggaraman di Pamekasan. ${ }^{4}$ Tidak semua petani garam merupakan pemilik lahan. Petani garam

\footnotetext{
Teodora Nirmala \& Rafael Sebayang \& Rikando Somba Fau, “Madura Tak Rasakan Legit Kristal Garam,” validnews.id, 2017, https://www.validnews.id/Madura-Tak-Rasakan-Legit-Kristal-Garam-V0000335.

2 Gemawan Dwi Putra, "Pulau Madura: Pulau Garam Indonesia," Indonesiabaik.id, 2018, http://indonesiabaik.id/infografis/ pulau-madura-pulau-garam-indonesia.

3 Abdul Basri, “4 Kabupaten Di Madura Masuk Daerah Termiskin,” Radar Madura, 2017, https://radarmadura.jawapos.com/

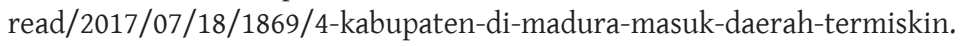

4 BPS Kabupaten and Pamekasan, "Banyaknya Penambang Garam Dan Luas Areal Pertambangan Garam Rakyat Menurut Kecamatan Di Kabupaten Pamekasan,” Badan Pusat Statistik Kabupaten Pamekasan, 2015, https://pamekasankab.bps. go.id/statictable/2017/06/14/246/banyaknya-penambang-garam-dan-luas-areal-pertambangan-garam-rakyat-menurutkecamatan-di-kabupaten-pamekasan-2015.html.
} 
yang mengerjakan lahan orang lain menggunakan sistem bagi hasil. Data menunjukkan 70,5 \% petani garam di Pamekasan menerapkan sistem bagi hasil. ${ }^{5}$

Mayoritas penduduk Pamekasan beragama Islam. Hal tersebut menunjukkan bahwa mayoritas petani garam di Pamekasan adalah beragama Islam. Islam sebagai sebuah agama tidak hanya bersifat transcendental, namun juga mengajarkan tentang ekonomi dan sosial kemasyarakatan. Pada sisi yang lain Indonesia adalah negara hukum. Setiap ada permasalahan dan persengketaan yang tidak dapat diselesaikan secara musyawarah dan kekeluargaan sudah semestinya melaui jalur hukum. Hal ini menunjukkan bahwa secara konstitusional persengketaan yang lahir karena adanya hak-hak yang tidak dipenuhi atau dilanggar dapat diselesaikan dan dijamin oleh hukum.

Selama ini memang tidak ada persengketaan dalam perjanjian bagi hasil antara petani penggarap dan pemilik lahan garam di Kabupaten Pamekasan yang bermuara di Pengadilan. Akan tetapi sebenarnya fungsi sebuah perjanjian selain sebagai alat bukti adalah sebagai sebuah dokumen yang berisi hak-hak para pihak. Sehingga apabila ada pihak yang haknya tidak terpenuhi dapat merasa terlindungi dan menuntut hak-haknya.

Berdasarkan pemaparan di atas ada beberapa hal yang perlu dibahas dalam artikle ini, yaitu pertama: bagaimana pola perjanjian bagi hasil antara petani penggarap dan pemilik lahan garam di Kabupaten Pamekasan?; kedua: bagaimana perlindungan petani penggarap lahan garam di Kabupaten Pamekasan dalam perspektif Hukum Islam dan Hukum Perdata?

\section{Konsep Perlindungan Hukum dalam Perspektif Hukum Perdata dan Hukum Islam}

Menurut Satjipto Raharjo perlindungan hukum dapat diwujudkan dengan menjamin pemberian hak kepada subjek hukum yang dirugikan oleh orang lain, termasuk hak asasi manusia. Tujuannya adalah agar semua orang dapat menikmati hak-hak yang diberikan oleh hukum. ${ }^{6}$

Philipus M. Hadjon berpendapat bahwa perlindungan hukum merupakan perlindungan terhadap harkat dan martabat serta pengakuan hak-hak asasi manusia yang dimiliki oleh subyek hukum berdasarkan ketentuan hukum. ${ }^{7}$ Menurut CST, Kansil perlindungan hukum adalah perlindungan yang diberikan oleh hukum terkait dengan interaksi sesama manusia sebagai subjek hukum sehingga melahirkan hak dan kewajiban yang harus dipenuhi sebagai akibat hukumnya. ${ }^{8}$ Dari pemaparan di atas dapat disimpulkan bahwa perlindungan hukum merupakan perlindungan terhadap hak-hak subjek hukum yang diatur oleh peraturan perundang-undangan akibat dari interaksinya dengan subjek hukum lainnya.

Perjanjian dalam KUHPerdata didefinisikan sebagai "suatu perbuatan yang terjadi antara satu atau dua orang atau lebih mengikatkan dirinya terhadap orang lain." Akan tetapi definisi ini menurut para pakar hukum masih belum lengkap dan terlalu luas. Hal tersebut dikarenakan pengikatan diri antara satu atau dua orang kepada orang lain dilakukan secara sepihak. Hal ini terlihat dari rumusan kalimat "yang terjadi antara satu orang atau lebih mengikatkan dirinya kepada satu orang atau lebih." Mengingat kelemahan tersebut, J. Satrio mengusulkan agar rumusan dirubah menjadi: "atau di mana kedua belah pihak saling mengikatkan diri."10

\footnotetext{
Sekretariat Daerah Kabupaten Pamekasan, "Pemetaan Potensi Garam Kabupaten Pamekasan," Sekdakab Pamekasan, 2015.

Satjipto Raharjo, Ilmu Hukum (Bandung: Citra Aditya Bakti, 2015), 56.

Philipus M. Hadjon, Perlindungan Bagi Rakyat Di Indonesia (Surabaya: Bina Ilmu, 1987), 2.

C.S.T. Kansil, Pengantar Ilmu Hukum Dan Tata Hukum Indonesia (Jakarta: Balai Pustaka, 1989), 102.

R \& R. Tjitrosudibio Subekti, Kitab Undang-Undang Hukum Perdata (Jakarta: Pradnya Paramita, 2003).

10 J. Satrio, Hukum Perikatan: Perikatan Yang Lahir Dari Perjanjian (Bandung: Citra Aditya Bakti, 1955), 27.
} 
Dikatakan terlalu luas, karena rumusan: "suatu perbuatan hukum" dapat mencakup perbuatan hukum (zaakwaarneming) dan perbuatan melawan hukum (onrechtmatigedaad). Suatu perbuatan melawan hukum memang dapat timbul karena perbuatan manusia dan sebagai akibatnya timbul suatu perikatan, yakni adanya kewajiban untuk melakukan transaksi tertentu yang berwujud ganti rugi kepada pihak yang dirugikan perbuatan melawan hukum jelas tidak didasarkan atau timbul dari perjanjian. ${ }^{11}$ Perjanjian kawin dalam hukum keluarga atau perkawinan pun berdasarkan rumusan perjanjian dalam Pasal 1313 KUHPerdata tersebut dapat digolongkan sebagai perjanjian. ${ }^{12}$

Pada dasarnya perjanjian merupakan sebuah kesepakatan yang dibuat oleh para pihak yang membuat perjanjian. Para pihak sepakat untuk mengikatkan diri satu dengan lainnya baik untuk memberikan sesuatu, berbuat sesuatu, atau tidak berbuat sesuatu. Kesepakatan ini akan melahirkan hak dan kewajiban diantara para pihak. Hak dan kewajiban tersebut harus bernilai ekonomis, dan oleh karenanya ia terletak dalam lapangan hukum kekayaan.

Salah satu kekuatan hukum yang bisa dijadikan perlindungan hukum para pihak dalam perjanjian adalah adanya asas pacta sunt servanda, yaitu bahwa "perjanjian yang dibuat secara sah oleh para pihak berlaku sebagai undang-undang bagi mereka yang membuatnya." 13 Pada umunya asas pacta sunt servanda dianut oleh negara-negara civil law seperti Indonesia. Asas ini dipengaruhi oleh hukum Kanonik yang mempunyai ajaran dasar bahwa setiap janji itu mengikat. ${ }^{14}$ Asas tersebut menimbulkan berbagai argumen di antaranya:

a. Asas daya mengikat kontrak dipahami sebagai mengikatnya kewajiban kontraktual yang harus dilaksanakan para pihak. Jadi pertama-tama makna daya mengikat kontrak tertuju pada isi atau prestasi kontraktualnya;

b. Pada dasarnya janji itu mengikat (pacta sun servada) sehingga perlu diberikan kekuatan untuk berlakunya. Untuk memberikan kekuatan daya berlaku atau daya mengikatnya kontrak, maka kontrak yang dibuat secara sah mengikat sera dikualifikasikan mempunyai kekuatan mengikat setara dengan daya berlaku berlaku dan mengikatnya undang-undang;

c. Asas pacta sunt servanda merupakan konsekuensi logis dari efek berlakunya kekuatan mengikat kontrak;

d. Kekuatan mengikat kontrak pada dasarnya hanya menjangkau sebatas para pihak yang membuatnya. Hal ini dalam beberapa literatur, khususnya di common law, disebut dengan "privity of contract";

e. Telaah lebih lanjut terkait perdebatan subtansi di atas kiranya dapat dipahami lebih komprehensif melalui pembahasan historis dan substansif berikut ini. Dengan demikian melalui analisis komprehensif akan diperoleh pemahaman yang tepat dan utuh mengenai konsep "daya mengikat kontrak "(the binding force of contract)", "pacta sunt servanda", maupun "privity of contract". ${ }^{15}$

Apabila ada pihak yang melakukan wanprestasi pihak yang dirugikan dapat menuntut hakhaknya, karena perjanjian merupakan undang-undang yang harus dipatuhi pasal-pasalnya yang telah

\footnotetext{
11 Satrio, 24.

12 Mariam Darus Badrulzaman, Aneka Hukum Bisnis (Bandung: Alumni Press, 1994), 18.

13 Subekti, Kitab Undang-Undang Hukum Perdata.

14 R. Wirjono Prodjodikoro, Asas-Asas Hukum Perjanjian (Bandung: Mandar Maju, 2011).

15 Agus Yudha Hernoko, Hukum Perjanjian Asas Proporsionalitas Dalam Kontrak Komersial (Jakarta: Kencana Prenada Media Group, 2010).
} 
disepakati. Munculnya potensi permasalahan dalam perjanjian sebagai akibat dari tidak terpenuhinya hak para pihak, maka konsep perlindungan hukum dalam hukum perdata merupakan conditio sine quanon. Adapun sarana perlindungan hukum yang digunakan adalah peraturan perundang-undangan dan asas-asas hukum dalam hukum perdata. Kedua hal ini yang kemudian dimplementasikan oleh pranata hukum yang ada, sepertia pengadilan atau lembaga penyelesaian sengketa non-litigasi. ${ }^{16}$

Selain asas pacta sunt servanda sebagai asas yang menunjukkan bahwa perjanjian itu mempunyai kekuatan mengikat para pihak, terdapat asas konsensualisme yang bermuara pada syarat sah perjanjian. Jadi, asas pacta sunt servanda bisa berlaku apabila syarat sah perjanjian terpenuhi. Adapun syarat-syarat sah dalam perjanjian ada empat, yaitu: kesepakatan, kecakapan, adanya hal tertentu dan causa halal. ${ }^{17}$

Terdapat pula ketentuan yang mengatur secara khusus mengenai perlindungan para petani penggarap garam selain ketentuan umum tentang perjanjian dalam KUHPerdata, yaitu UU Nomor 7 Tahun 2016 tentang Perlindungan dan Pemberdayaan Nelayan, Pembudidaya Ikan dan Petambak Garam. Strategi perlindungan yang diatur dalam undang-undang tersebut melalui: "penyediaan prasarana usaha pergaraman, kemudahan memperoleh sarana usaha pergaraman, jaminan kepastian usaha, jaminan resiko pergaraman, penghapusan praktik ekonomi biaya tinggi, pengendalian komoditas pergaraman, jaminan keamanan dan keselamatan; dan fasilitasi dan bantuan hukum." ${ }^{18}$

Meskipun undang-undang di atas membahas tentang perlindungan petambak garam, namun apabila dilihat pada poin yang berkaitan dengan hukum undang-undang di atas hanya berbunyi "fasilitasi dan bantuan hukum". ${ }^{19}$ Dengan demikian apabila ada sengketa antara petani penggarap dan pemilik lahan garam, hal yang dijamin oleh undang-undang tersebut hanya sebatas bantuan hukum saja. Hal tersebut berarti apabila perjanjian yang telah disepakati, sebagai undang-undang pertama mereka, tidak menjamin hak-hak para petani penggarap garam, maka akibat hukumnya juga kurang atau bahkan tidak melindungi hak-hak mereka. Oleh sebab itu hal terpenting dalam hubungan kerja sama antara petani penggarap dan pemilik lahan garam adalah terbentuknya perjanjian yang sesuai peraturan perundang-undangan.

Menurut Islam terbentuknya sebuah perjanjian sebagai dasar untuk memperoleh sesuatu dengan cara yang halal dan benar wajib dilindungi baik oleh individu maupun masyarakat. ${ }^{20}$ Perjanjian dalam Islam disebut dengan istilah akad, yaitu "kesepakatan antara dua pihak atau lebih dalam suatu perjanjian untuk melakukan dan atau tidak melakukan perbuatan hukum tertentu." ${ }^{11}$ Akad sah apabila terpenuhi rukun dan syaratnya.22 Adapun rukun-rukun akad yaitu: pihak-pihak yang berakad; obyek akad; tujuan pokok akad; kesepakatan. ${ }^{23}$

Menurut hukum Islam agar dikatakan sah dan mengikat para pihak sebagaimana undangundang, sebuah perjanjian harus didasarkan pada asas-asas akad. ${ }^{24}$ Penerapan asas-asas akad tersebut

\footnotetext{
16 M. Natsir Asnawi, "Perlindungan Hukum Kontrak Dalam Perspektif Hukum Kontemporer," Masalah-Masalah Hukum 46, no. 1 (2017): 55-68, https://doi.org/10.14710/mmh.46.1.2017.55-68.

17 Subekti, Kitab Undang-Undang Hukum Perdata.

18 Negara Republik Indonesia, "UU Nomor 7 Tahun 2016 Tentang Perlindungan Dan Pemberdayaan Nelayan, Pembudidaya Ikan Dan Petambak Garam” (2016).

19 Negara Republik Indonesia.

20 Nita Triana, "Menggagas Hak Kekayaan Intelektual Perspektif Hukum Islam Ke Dalam Hukum Nasional," Al-Manahij: Jurnal Kajian Hukum Islam 12, no. 2 (2018): 177-92.

21 Mahkamah Agung Republik Indonesia, “Kompilasi Hukum Ekonomi Syariah” (2008).

22 Mahkamah Agung Republik Indonesia.

${ }_{23}$ Mahkamah Agung Republik Indonesia.

24 Syamsul Anwar, Hukum Perjanjian Syariah: Studi Tentang Teori Akad Dalam Fikih Muamalat (Jakarta: Rajawali, 2010), 15.
} 
agar hak-hak para pihak terlindungi, antara lain adalah asas ikhtiyari atau sukarela, maksudnya setiap akad yang dilakukan harus berdasar atas kehendak para pihak, tidak boleh ada keterpaksaan dan tekanan dari pihak lainnya. Berikutnya adalah asas taswiyah atau kesetaraan yang mengharuskan para pihak mempunyai bargaining position yang sama, sehingga dapat tercapai hak dan kewajiban yang setara. ${ }^{25}$

Menurut hukum Islam akad terjadi apabila ada kesepakatan antar pihak yang melakukannya. Hal ini mengandung makna bahwa setiap perjanjian yang diadakan oleh kedua pihak merupakan perbuatan yang sakral (spiritual) dan bersifat transenden. ${ }^{26}$ Pemenuhan akad-akad merupakan perintah Allah dan menjadi bentuk ketaatan kepada Allah. Orang yang melanggar akad perjanjian mendapatkan dosa, orang menepatinya mendapatkan pahala. Allah swt berfirman:

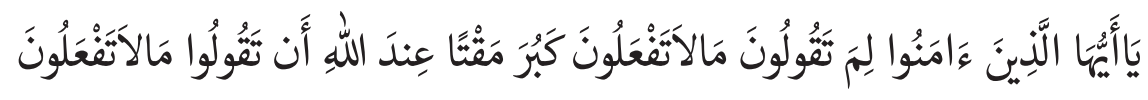

"Wahai orang-orang yang beriman, mengapa kamu mengatakan sesuatu (berjanji) tetapi kamu tidak melaksanakannya. Allah sangat membenci orang-orang yang berjanji (mengatakan sesuatu) tapi tidak melaksanakan janjinya (perkataannya) itu".

Berdasarkan ayat itu, disimpulkan bahwa setiap akad perjanjian itu bersifat mengikat para pihak dan wajib ditepati. Asas-asas lainnya terkait dengan perlindungan para pihak adalah asas taswiyah atau kesetaraan. ${ }^{27}$ Asas ini mengharuskan para pihak memiliki kedudukan yang setara dalam setiap akad. Implikasinya adalah keseimbangan hak dan kewajiban yang diatur dalam akad tersebut. Asas ini biasanya dalam sebuah perjanjian termanifestasikan melalui proses tawar menawar antara kedua belah pihak. Jadi adanya proses tawar menawar merupakan implementasi dari asas taswiyah atau kesetaraan.

Asas yang terkait dengan asas di atas adalah asas transparansi. ${ }^{28}$ Hak dan kewajiban yang dirumuskan dalam proses tawar menawar dan sudah disepakati oleh para pihak harus dilaksanakan dengan pertanggungjawaban para pihak secara terbuka. Bentuk keterbukaan salah satunya adalah dengan mengemukakan hasil atau harga yang sebenarnya. Sehingga ketika proses pembagian keuntungan tidak ada yang dirugikan, begitu juga ketika ada kerugian harus disampaikan secara terbuka, tidak ditutup-tutupi dan tidak disampaikan dengan menaikkan harga (mark up).

Selain asas-asas itu juga terdapat beberapa prinsip berakad dalam Al-Qur'an. Pertama prinsip yang menyatakan bahwa akad hendaknya tertulis, sebagaimana firman Allah SWT: "Hai orang-orang yang beriman, apabila kalian bermuamalah tidak secara tunai untuk waktu yang ditentukan, hendaklah kalian menuliskannya..."29 Ibnu Katsir dalam tafsirnya menyatakan bahwa catatan atau kontrak itu lebih memelihara dan menjamin kepastian orang yang membuatnya serta lebih tegas bagi orang yang menyaksikannya. ${ }^{30}$ Hikmah dari firman tersebut adalah berkaitan dengan pembuktian, yaitu akan memperkuat kesaksian. Hal tersebut dinyatakan dalam firman Allah SWT “...yang demikian itu lebih

\footnotetext{
25 Mahkamah Agung Republik Indonesia, Kompilasi Hukum Ekonomi Syariah.

26 Fathurrahman Djamil, Penerapan Hukum Perjanjian Dalam Transaski Di Lembaga Keuangan Syariah (Jakarta: Sinar Grafika, 2012), 24.

27 Mahkamah Agung, Kompilasi Hukum Ekonomi Syariah.

28 Mahkamah Agung.

29 Departemen Agama RI, Al-Qur'an Terjemah Asbabu al-Nuzul.48

30 Ibnu Katsir, Tafsir Al-Qur'an al-'Adzim (Beirut: Dar al-Fikr, 2009).
} 
adil di sisi Allah dan lebih dapat menguatkan kesaksian dan lebih dekat kepada tidak (menimbulkan) kerugian kalian." ${ }^{1}$

Kedua adalah prinsip persaksian, sebagaimana firman Allah SWT: “...dan persaksikanlah dengan dua orang saksi dari orang laki-laki (diantara kalian)...".32 Ayat tersebut menyebutkan selain catatan atau kontrak agar lebih memperkuat kepercayaan hendaknya ada dua orang saksi. Catatan dan kesaksian merupakan dua prinsip utama yang sebaiknya diwujudkan dalam setiap perjanjian yang disepakati.

Ketentuan tentang perjanjian bagi hasil antara petani penggarap dan pemilik lahan garam dalam konteks hukum ekonomi Islam mengacu kepada akad muzāra'ah. Ada beberapa ketentuan perjanjian bagi hasil dalam hukum ekonomi Islam, misalnya akad mudharabah dan musyarakah. Namun dalam konteks perjanjian bagi hasil antara petani penggarap dan pemilik lahan garam lebih tepatnya menggunakan akad muzära'ah. Hal tersebut dapat dilihat dari karakteristik objek perjanjiannya, yaitu sebuah lahan tambak garam yang dimiliki oleh pemilik lahan dan jasa petani penggarap.

Definisi akad muzāra'ah adalah kerja sama pengolahan tanah oleh penggarap dan pemilik lahan dengan bagi hasil pertanian, dengan bibit pertanian disediakan oleh penggarap. ${ }^{33}$ Menurut Yusuf Qordhawi, muzāra'ah adalah akad kerjasama pertanian dengan cara pemilik tanah menyerahkan alat dan benih dan kepada yang hendak menanaminya dengan suatu ketentuan dia akan mendapat hasil yang telah ditentukan, misalnya: $1 / 2,1 / 3$ atau kurang atau lebih menurut pesetujuan bersama. ${ }^{34}$ Berikut ini adalah rukun dan syarat akad muzära'ah: ${ }^{35}$

Menurut jumhur ulama rukun akad muzāra'ah adalah: pemilik lahan, petani penggarap, objek muzāra'ah dan ijab qabul. Sedangkan syarat-syarat akad muzāra'ah terkait dengan syarat-syarat yang harus dipenuhi oleh unsur-unsur dalam rukun akad muzāra'ah, yaitu:

1. Orang yang berakad (aqidain)

Orang yang melakukan akad, dalam hal ini adalah pemilik lahan dan petani penggarap, disyaratkan bahwa keduanya harus orang yang telah baligh dan berakal, karena kedua syarat inilah yang membuat seseorang dianggap cakap hukum. Selain itu pihak pemilik lahan dan penggarap juga disyaratkan harus bukan orang yang murtad.

2. Objek muzāra'ah

Berikut ini adalah ketentuan mengenai objek muzāra'ah:

a. Lahan pertanian yang akan dikelola berasal dari pemilik tanah, sedangkan modal dan pengelolaan berasal dari petani penggarap.

b. Lahan pertanian yang akan diolah berasal dari pemilik lahan, pengelolaan berasal dari petani penggarap, sedangkan modal berasal dari keduanya baik penggarap maupun pemilik lahan sama-sama memberikan modal.

Berkaitan dengan ketentuan di atas, maka ada empat bentuk akad muzāra'ah: ${ }^{36}$

a. Apabila lahan dan bibit dari pemilik lahan, kerja dan alat dari petani, sehingga yang menjadi objek muzāra'ah adalah jasa petani, maka hukumnya sah.

\footnotetext{
31 Departemen Agama RI, Al-Qur'an Terjemah Asbabu al-Nuzul.

32 Departemen Agama RI.

33 Abdul Rahman Ghazaly, dkk, Fiqih Muamalat, cet. Ke-4 (Jakarta: Prenadamedia Group, 2015).114

${ }_{34}$ Yusuf Qardhawi, Halal Dan Haram Dalam Islam, ed. Tim Kuadran (Bandung: Jabal Press, 2007), 284.

35 Hendi Suhendi, Fiqih Muamalah (Jakarta: Raja Grafindo Persada, 2006), 158.

36 Wahbah al- Zuhaily, Al-Figh Al-Islam Wa Adillatuh, ed. Abdul Hayyie al-Kattani (Jakarta: Gema Insani Press, 2011).
} 
b. Apabila pemilik lahan hanya menyediakan lahan, sedangkan petani menyediakan bibit, alat dan kerja, sehingga yang menjadi objek muzāra'ah adalah manfaat lahan, maka akad muzāra'ah juga sah.

c. Apabila alat, lahan dan bibit dari pemilik lahan dan kerja dari petani, sehingga yang menjadi objek muzāra'ah adalah jasa petani, maka akad muzāra'ah juga sah.

d. Apabila lahan pertanian dan alat disediakan pemilik lahan sedangkan bibit dan kerja dari petani, maka akad ini tidak sah. Hal ini dikarenakan alat pertanian lebih berhubungan dengan petani, sementara bibit lebih kepada pemilik lahan. ${ }^{37}$ Kecuali petani hanya mengerjakan saja, sementara pemilik lahan membiayai semuanya baru diperbolehkan, sebagaimana poin c.

3. Ijab dan Qabul

Menurut Hanabilah, dalam akad muzāra'ah tidak diperlukan qabul dengan perkataan, melainkan cukup dengan penggarapan tanah secara langsung. Dengan demikian qabul tersebut dinyatakan dalam bentuk tindakan bukan perkataan. ${ }^{38}$

4. Jangka waktu perjanjian akad muzāra'ah

Selain syarat-syarat yang berkaitan dengan rukun muzāra'ah ada pula syarat yang menyangkut dengan waktu perjanjian. Menurut jumhur ulama, syarat sahnya muzāra'ah yang lain adalah menjelaskan jangka waktu sejak awal perjanjian, sehingga muzāra'ah sendiri tidak sah apabila tanpa adanya penentuan batas waktu dalam pelaksanaannya.

Pada dasarnya ketentuan-ketentuan perjanjian menurut hukum ekonomi Islam di atas merupakan ius constituendum yang kemudian menjadi ius constitutum, salah satunya berbentuk peraturan Mahkamah Agung Nomor 2 Tahun 2018 tentang Kompilasi Hukum Ekonomi Syariah. ${ }^{39}$ Sehingga apabila ada sengketa antara para pihak dapat menggunakan peraturan di atas sebagai landasan hukumnya.

Dari pemaparan di atas dapat disimpulkan dan dibuat indikator-indikator perlindungan hakhak para pihak dalam perjanjian bagi hasil antara petani penggarap dan pemilik lahan garam sebagai berikut:

1. Perjanjian bagi hasil atas lahan garam dibuat oleh pemilik lahan bersama dengan penggarapnya;

2. Ada proses tawar menawar sebelum terjadi perjanjian;

3. Perjanjian bagi hasil dibuat secara tertulis;

4. Pembagian persentase/model bagi hasil (1/2 atau $1 / 3$ atau $1 / 4$ atau lainnya) sudah jelas pada awal perjanjian;

5. terdapat dua orang saksi dalam perjanjian tersebut dan diketahui oleh kepala desa;

6. Jangka waktu perjanjian ditentukan secara tegas batas maksimum dan minimumnya;

7. Praktek di lapangan sesuai dengan isi perjanjian;

8. Problematika muncul selama penggarapan lahan.

\footnotetext{
37 M. Ali Hasan, Berbagai Macam Transaksi Dalam Islam: Fiqih Muamalah (Jakarta: Raja Grafindo Persada, 2004), 277.

38 Abdul Azis. et.al Dahlan, Ensiklopedi Hukum Islam (Jakarta: Ichtiar Baru Van Hoeve, 2006), 1273.

39 Achmad Badarus Syamsi, "Transformasi Hukum Ekonomi Islam Sebagai Ius Constituendum Menjadi Ius Constitutum," EtTijarie: Jurnal Hukum Dan Bisnis Syariah 4, no. 1 (2017).
} 


\section{Pola Bagi Hasil Petani Garam di Kabupaten Pamekasan}

Perjanjian bagi hasil lahan pertanian merupakan suatu kesepakatan yang terjadi antara pemilik lahan pertanian dengan petani penggarap lahan dalam usaha yang dijalani bersama untuk mengelola lahan pertanian dengan keuntungan dibagi menurut kesepakatan bersama. Perjanjian bagi hasil adalah perjanjian dengan nama apapun juga yang diadakan antara pemilik tanah dengan penggarap dengan perjanjian bahwa penggarap diperkenankan oleh pemilik lahan untuk menyelenggarakan usaha pertanian, dengan pembagian hasil antara kedua belah pihak.

Perjanjian dalam sistem bagi hasil responden dilakukan secara lisan atas dasar saling percaya antara kedua belah pihak tanpa mengikut sertakan pihak ketiga sebagai saksi. Hal tersebut sudah menjadi kebiasaan warga setempat dan dilakukan secara turun-temurun. Perjanjian tersebut meskipun tanpa dihadiri oleh para saksi dan dihadapan perangkat desa dianggap sudah tidak lagi dipermasalahkan, meskipun terdapat masalah akan diselesaikan secara kekeluargaan. Terdapat hal yang menarik dalam perjanjian tersebut yakni tidak adanya batas yang jelas (batas minimum atau maksimum) dan hanya disebutkan bahwa perjanjian tersebut berlaku selama mereka mampu menggarap atau selama petani/penggarap masih hidup.

Adapun mengenai bagi hasilnya terdapat dua pola yang banyak digunakan dan beberapa yang berbeda. Dua pola yang umum digunakan yaitu bagi dua atau paron $(1 / 2)$ dan bagi tiga atau pertelon (1/3). Sementara pola yang berbeda dari dua pola tersebut adalah $2 / 5$ dan $1 / 5$.

Table 1: Jumlah penggunaan pola bagi hasil

\begin{tabular}{ccc}
\hline No. & Pola Bagi Hasil & Responden \\
\hline 1 & $1 / 2$ & 2 \\
2 & $1 / 3$ & 38 \\
3 & $1 / 5$ & 2 \\
4 & $2 / 5$ & 2 \\
5 & Pola lain & 8 \\
\hline
\end{tabular}

Hak yang diperoleh dan kewajiban yang harus dijalankan oleh petani penggarap pada setiap pola bagi hasil relatif sama, tidak terlalu berbeda. Salah satu hal yang membedakan keduanya, yakni kewajiban petani penggarap pola paron (1/2) adalah bertanggungjawab atas kerusakan lahan garam secara penuh. Sedangkan, petani penggarap pada pola pertelon (1/3) tidak memiliki kewajiban ini dikarenakan lahan garam pola ini berada dalam kondisi yang baik untuk berproduksi. Apabila ada lahan garam yang mengalami kerusakan, maka biaya ditanggung bersama, baik oleh petani penggarap maupun pemilik lahan. Namun, kerusakan lahan garam pada pola pertelon (1/3) jarang terjadi dan biasanya nilai biaya perbaikan lahan garam pola ini pun tidak sebesar lahan garam pola paron (1/2). Pada umumnya kondisi lahan garam pada pola paron (1/2) adalah lahan garam baru atau lahan garam yang sering mengalami kerusakan sehingga membutuhkan biaya perawatan lahan garam yang besar. Hal tersebut terlihat sederhana, namun biaya tambahan perbaikan lahan ini cukup besar nilainya.

Adapun hak dan kewajiban petani penggarap dan pemilik lahan garam pola $1 / 5$, pola yang jarang digunakan, lebih kepada perjanjian antara pemilik lahan dan petani penggarap sebagai buruh. Hal ini mengakibatkan hasil yang diterima oleh petani penggarap tidak sebanyak pola paron dan 
pertelon. Berdasarkan hasil survei salah satu hal yang mempengaruhi pemilik lahan menerapkan pola ini adalah latar belakang pendidikan pemilik lahan, yaitu sarjana strata satu.

Selain hal-hal di atas petani penggarap juga memperoleh hak tempat tinggal berupa bilik, dalam bahasa Madura dikenal dengan istilah 'bidhik', yang terbuat dari kayu bambu di dalamnya berisi peralatan tidur dan masak, seperti kompor, wajan, dan peralatan masak lainnya. 'Bidhik' ini biasanya dihuni oleh petani penggarap dan istrinya atau terkadang dihuni oleh petani penggarap saja. Letak 'bidhik' tidak jauh dengan lahan garam yang dikelola oleh petani penggarap. Hal ini bertujuan agar petani penggarap dapat mengontrol kondisi lahan garam yang dikelola. Selain itu, 'bidhik' ini dapat digunakan sebagai tempat bernaung atau beristirahat ketika waktu istirahat di siang hari tiba. Meskipun 'bidhik' ini jauh dari kata layak tinggal, namun dapat mengurangi biaya tempat tinggal bagi para petani penggarap.

Hak memperoleh peralatan produksi, seperti kincir angin, pompa air, sedong, slender, baumeter, dan peralatan pendukung lainnya. Jika petani penggarap membutuhkan peralatan produksi yang lebih banyak atau peralatan produksi yang diberikan mengalami kerusakan, maka petani penggarap harus menyediakan dan atau memperbaiki peralatan tersebut. Jika di kemudian hari, biaya perbaikan alat produksi terlalu tinggi, maka pemilik lahan biasanya akan memberikan bantuan dana.

Bantuan dana biasanya penanggungan bersama atas biaya perbaikan atau pembelian peralatan produksi tersebut. Hak memperoleh pinjaman sesuai dengan yang diajukan oleh petani penggarap. Biasanya petani penggarap akan mengajukan pinjaman di awal musim produksi. Pemilik lahan tentu dengan sendirinya telah menyiapkan sejumlah uang sebagai pinjaman kepada petani penggarap yang akan mengelola lahan miliknya. Hak ini disesuaikan dengan kewajiban yang harus dilakukan oleh petani penggarap, yakni mengembalikan pinjaman. Jangka waktu yang diberikan untuk mengembalikan pinjaman tersebut dapat dikatakan tidak terbatas. Artinya, jika petani penggarap tidak mampu membayar pada akhir musim ini, pinjaman tersebut akan dihitung dan diakumulasikan pada pinjaman di musim berikutnya. Hal yang menarik adalah tidak diberlakukannya bunga atas pinjaman ini. Namun jika dianalisis, bunga yang seharusnya diberlakukan oleh pemilik lahan diperoleh secara tidak langsung dari biaya pinjaman yang sangat tinggi nilainya.

Petani penggarap kurang menyadari hal ini. Telah diketahui bersama, bahwa petani penggarap yang terlibat dalam suatu pola bagi hasil tertentu memiliki kewajiban untuk menjual garam produksinya kepada pemilik lahan. Hal ini telah menjadi kelumrahan dalam pola bagi hasil. Hubungan antara petani penggarap dan pemilik lahan dapat dikatakan sebagai hubungan 'timbal balik' atau 'hubungan saling menguntungkan', meskipun tidak sepenuhnya benar.

\section{Kajian Ekonomi Islam Pola Bagi Hasil Petani Garam di Kabupaten Pamekasan}

Akad perjanjian kerjasama pertanian dalam muamalah sering dikenal dengan istilah mukhābarah dan muzāra'ah. Mukhābarah adalah kerjasama pengolahan pertanian antara pemilik lahan dan penggarap, dengan imbalan bagi hasil dari hasil panen dimana benih berasal dari penggarap, sedangkan pengertian muzāra'ah hampir sama dengan mukhābarah dimana yang membedakan hanyalah benih berasal dari pihak pemilik lahan. Dalam penelitian ini penulis hanya menggunakan konsep akad muzāra'ah.

Ketentuan-ketentuan yang harus dipenuhi agar sebuah perjanjian sesuai dengan prinsip ekonomi Islam, dalam hal ini akad muzāra'ah, adalah sebagai berikut: 
1. Orang yang berakad (aqidain). Rukun dalam akad muzära'ah dan mukhäbarah yang pertama terdiri dari pemilik lahan (mālik) dan penggarap ('āmil). Untuk orang yang melakukan akad disyaratkan bahwa keduanya harus orang yang telah baligh dan berakal, karena kedua syarat inilah yang membuat seseorang dianggap cakap hukum. Selain itu pihak pemilik lahan dan penggarap juga disyaratkan harus bukan orang yang murtad. Praktek perjanjian bagi hasil di Kabupaten Pamekasan yang terjadi terkait dengan orang yang berakad dilakukan oleh pemilik lahan dan penggarap. Keduanya merupakan oarng yang sudah baligh dan berakal sehat serta bukan merupakan orang yang murtad. Berdasarkan keterangan di atas, maka praktek perjanjian bagi hasil pertanian garam terkait dengan aqidain yang dilakukan oleh semua responden di Kabupaten Pamekasan sudah sesuai dengan hukum Islam.

2. Ijab dan Qabul. Praktek ijab dan qabul dalam perjanjian kerjasama pertanian garam di Kabupaten Pamekasan yang dilakukan oleh responden dalam bentuk pernyataan lisan saja dan tanpa menghadirkan saksi. Menurut Hanabilah, dalam akad muzāra'ah tidak diperlukan qabul dengan perkataan, melainkan cukup dengan penggarapan tanah secara langsung. Dengan demikian qabul tersebut dinyatakan dalam bentuk perkataan. Berdasarkan keterangan di atas maka praktek ijab dan qabul dalam perjanjian bagi hasil pertanian garam di Kabupaten Pamekasan yang dilakukan oleh para responden sesuai dengan hukum Islam, meskipun hanya dilakukan secara lisan dan tanpa adanya saksi.

3. Modal. Pelaksanaan akad perjanjian kerjasama pertanian yang terjadi di Kabupaten Pamekasan terkait dengan modal yaitu sebagai berikut: a) Lahan pertanian yang akan dikelola berasal dari pemilik tanah, sedangkan modal dan pengelolaan berasal dari petani penggarap. b) Lahan pertanian yang akan diolah berasal dari pemilik lahan, pengelolaan berasal dari petani penggarap, sedangkan modal berasal dari keduanya baik penggarap maupun pemilik lahan sama-sama memberikan modal. c) Berkaitan dengan modal (benih) dari akad muzāra'ah, Muhammad bin Hasan asy-Syaibani menyatakan bahwa dilihat dari segi sah atau tidaknya akad muzāra'ah, maka ada empat bentuk akad muzāra'ah: a) Apabila lahan dan bibit dari pemilik lahan, kerja dan alat dari petani, sehingga yang menjadi objek muzāra'ah adalah jasa petani, maka hukumnya sah. b) Apabia pemilik lahan hanya menyediakan lahan, sedangkan petani menyediakan bibit, alat dan kerja, sehingga yang menjadi objek muzāra'ah adalah manfaat lahan, maka akad muzāra'ah juga sah. c) Apabila alat, lahan dan bibit dari pemilik lahan dan kerja dari petani, sehingga yang menjadi objek muzāra'ah adalah jasa petani, maka akad muzāra'ah juga sah. d) Apabila lahan pertanian dan alat disediakan pemilik lahan sedangkan bibit dan kerja dari petani, maka akad ini tidak sah. Berdasarkan praktek yang terjadi di atas, maka pelaksanaan perjanjian bagi hasil pertanian yang dilakukan oleh para responden di Kabupaten Pamekasan dilihat dari segi modal sebagian sudah ada yang sesuai dengan hukum Islam, dan semua itu dilakukan berdasarkan suka rela dan tidak ada unsur keterpaksaan di dalamnya atas dasar rasa saling tolong menolong.

4. Jangka waktu perjanjian akad muzāra'ah. Perjanjian kerjasama pertanian garam yang dilakukan oleh para responden di Kabupaten Pamekasan dalam akadnya tidak menyatakan secara jelas jangka waktu atau masanya. Menurut jumhur ulama, syarat sahnya muzāra'ah 
yang lain adalah menjelaskan jangka waktu sejak awal perjanjian, sehingga muzāra'ah sendiri tidak sah apabila tanpa adanya penentuan batas waktu dalam pelaksanaannya.

\section{Perlindungan Hukum Perjanjian Bagi Hasil Petani Garam di Kabupaten Pamekasan}

Perlindungan hukum terhadap petani penggarap lahan garam di Kabupaten Pamekasan dianalisa berdasarkan hasil temuan melalui indikator-indikator di bawah ini:

Tabel 2. Indikator Perlindungan Petani Garam

\begin{tabular}{llcc}
\hline \multirow{2}{*}{ No } & Indikator & \multicolumn{2}{c}{ Jawaban } \\
\cline { 3 - 4 } & & Ya & Tidak \\
\hline 1 & $\begin{array}{l}\text { Perjanjian bagi hasil atas lahan garam dibuat oleh pemilik lahan bersama } \\
\text { dengan penggarapnya }\end{array}$ & 2 \\
2 & Ada proses tawar menawar sebelum terjadi perjanjian & 16 & 36 \\
3 & Perjanjian bagi hasil dibuat secara tertulis & 2 & 50 \\
4 & $\begin{array}{l}\text { Pembagian prosentase/model bagi hasil (1/2 atau 1/3 atau lainnya) sudah } \\
\text { jelas pada awal perjanjian. }\end{array}$ & 48 & 4 \\
5 & $\begin{array}{l}\text { Di dalam perjanjian tersebut terdapat dua orang saksi dan diketahui oleh } \\
\text { kepala desa }\end{array}$ & 2 & 50 \\
6 & Jangka waktu perjanjian ditentukan secara tegas batas maksimum dan & 9 & 43 \\
& minimumnya & & \\
7 & Praktek di lapangan sesuai dengan isi perjanjian & 48 & 4 \\
8 & Problematika muncul selama penggarapan lahan & 6 & 46 \\
\hline
\end{tabular}

Berdasarkan data yang didapat dari responden, sebagaimana tersaji dalam tabel 1 (satu), petani garam di kabupaten Pamekasan belum cukup terlindungi. Hal tersebut dilihat dari dua indikator penting yaitu perjanjian antara petani dan pemilik lahan garam yang tidak dibuat secara tertulis dan tidak adanya saksi dalam perjanjian tersebut. Namun demikian, perjanjian antara petani dan pemilik garam sudah sesuai dengan syarat sah perjanjian yang termaktub dalam pasal 1320 KUHPerdata. Syarat subjektif berupa kesepakatan dapat diketahui dari indikator nomor satu, $96 \%$ responden menyatakan membuat perjanjian dengan pemilik lahan. Syarat kecakapan terlihat dari data responden yang berumur di atas 20 tahun. Adapun syarat objektif berupa hal tertentu dan causa halal sudah jelas sesuai.

1. Perjanjian bagi hasil atas lahan garam dibuat oleh pemilik lahan bersama dengan penggarapnya. Pada dasarnya semua praktek kerjasama bagi hasil antara petani penggarap dan pemilik lahan garam dilakukan berdasarkan perjanjian baik dilakukan secara lisan maupun tertulis. Berdasarkan hasil survei hanya 3\% responden yang dilakukan tidak berdasar perjanjian bagi hasil, karena digarap sendiri dan untuk beberapa pekerjaan digarap atau dikerjakan oleh orang dengan sistem buruh.

2. Ada proses tawar menawar sebelum terjadi perjanjian. Proses bargaining merupakan unsur terpenting yang ada dalam sebuah perjanjian. Hal itu untuk melindungi kepentingan dan hak para pihak. Hasil survei menunjukkan adanya proses tawar menawar hanya sekitar $30 \%$. Hal 
demikian terjadi karena hak dan kewajiban petani penggarap dan pemilik lahan garam sudah umum dan maklum dalam masyarakat Kabupaten Pamekasan. Sementara terjadinya proses tawar menawar sebanyak 30\% dari semua responden menunjukkan adanya hak baru yang belum muncul pada perjanjian bagi hasil, salah satunya karena pola yang digunakan bukanlah pola yang umum, misalnya $1 / 5$ dan $2 / 5$. Sedangkan untuk pola paron dan pertelon umumnya langsung sepakat. Indikator ini merupakan implementasi dari salah satu asas dalam hukum ekonomi islam yaitu asas taswiyah atau kesetaraan yang bermuara pada kesetaraan dan keseimbangan hak dan kewajiban para pihak. Tawar menawar merupakan bentuk nyata dari adanya kesetaraan kedudukan antara kedua belah pihak.

3. Perjanjian bagi hasil dibuat secara tertulis. Masyarakat melakukan perjanjian bagi hasil ini lebih kepada asas kepercayaan, sehingga untuk membuat perjanjian secara tertulis tidak dilakukan. Kalau pun ada perjanjian tertulis itu lebih kepada perjanjian sewa lahan digabungkan dengan perjanjian bagi hasil. Poin ini merupakan substansi dari kekuatan pembuktian sebuah perjanjian, baik dalam hukum perdata maupun hukum Islam. Hasil survei sebanyak 97\% responden yang membuat perjanjian secara tidak tertulis. Hal itu berarti perlindungan hukum petani penggarap lahan garam, apabila ada sengketa, sangat minim sekali. Sebagaimana diketahui bahwa alat bukti dalam hukum acara perdata ada tulisan/surat, saksi, persangkaan, pengakuan dan sumpah. ${ }^{40}$ Adapun alat bukti tulisan yang paling kuat adalah akta otentik, yaitu akta yang format dan bentuknya ditentukan oleh undang-undang dan dibuat di hadapan pejabat yang berwenang untuk itu di tempat akta itu dibuat. ${ }^{41}$ Dalam hal ini perjanjian bagi hasil bias dibuat di depan Notaris. Namun apabila tidak dalam bentuk akta notaris pun sebuah perjanjian masih mempunyai kekuatan pembuktian asal dibuat dalam bentuk akta dibawah tangan, yaitu sebuah akta atau perjanjian yang sengaja dibuat untuk pembuktian para pihak tanpa bantuan dari pejabat yang berwenang, semata-mata demi melindungi kepentingan para pihak. ${ }^{42}$

4. Pembagian persentase/model bagi hasil (1/2 atau $1 / 3$ atau lainnya) sudah jelas pada awal perjanjian. Implementasi pembagian keuntungan sudah jelas dan umum pada beberapa pola yang banyak digunakan seperti paron dan pertelon serta beberapa pola baru. Sehingga para pihak dapat mengetahui dengan jelas bagiannya. Adapun $8 \%$ responden yang menyatakan tidak jelas, salah satu faktornya karena mereka lebih sebagai buruh dari pemilik lahan atau dari keterangan di atas menggunakan pola $2 / 5$.

5. Terdapat dua orang saksi dalam perjanjian tersebut dan diketahui oleh kepala desa. Sebagaimana perjanjian yang dilakukan secara lisan karena berdasar asas kepercayaan, pun demikian dengan hasil responden yang menyatakan $97 \%$ tidak ada saksi dalam perjanjian. Kesaksian merupakan kepastian yang disampaikan secara lisan dan pribadi oleh seseorang yang bukan salah satu dari pihak yang sedang bersengketa tentang peristiwa yang dipersengketakan kepada hakim dalam sebuah persidangan. ${ }^{43}$ Minimal terdapat dua orang saksi yang dimintai keterangan agar kesaksiannya dianggap sebagai alat bukti yang sah. "Unus testis nullus testis", keterangan seorang saksi saja tidak dapat dipercaya dan dijadikan alat bukti. ${ }^{44}$ Seharusnya setiap perjanjian bagi

\footnotetext{
40 Kitab Undang-undang Hukum Perdata.

${ }^{41}$ Kitab Undang-undang Hukum Perdata.

42 Sudikno Mertokusumo, Hukum Acara Perdata Indonesia (Yogyakarta: Liberty, 2006).134

Sudikno Mertokusumo.166

44 Kitab Undang-undang Hukum Perdata.
} 
hasil diketahui oleh kepala desa dan dipersaksikan oleh dua orang masing-masing dari petani penggarap dan pemilik lahan. Hal tersebut sebenarnya merupakan ketentuan lama sebagaimana termaktub dalam undang-undang perjanjian bagi hasil. ${ }^{45}$

6. Jangka waktu perjanjian ditentukan secara tegas batas maksimum dan minimumnya. Praktek perjanjian bagi hasil pertanian garam di Kabupaten Pamekasan dilakukan dengan jangka waktu seumur hidup. Hal tersebut disepakati karena sudah menjadi kebiasaan di daerah tersebut. Sedangkan sebanyak 17\% responden yang menentukan jangka waktunya karena sistem yang digunakan lebih pada sewa menyewa lahan tidak murni perjanjian bagi hasil.

7. Praktek di lapangan sesuai dengan isi perjanjian. Penerapan perjanjian bagi hasil antara petani penggarap dan pemilik lahan garam menurut $92 \%$ responden sudah sesuai dengan kesepakatan awal perjanjian mereka. Hak yang diperoleh dan kewajiban yang dilaksanakan oleh para pihak sudah sesuai kesepakatan awal. Sedangkan sisanya sebanyak $8 \%$ responden menyatakan ada perubahan pembagian hasil keuntungan. Hal tersebut dikarenakan dua faktor, pertama karena peralatan yang dikarenakan peralatan yang disediakan oleh pemilik lahan tidak mencukupi, sehingga petani penggarap harus mencari sendiri. Kedua, faktor naik turunnya harga garam. Jadi apabila harga garam mengalami penurunan, pihak pemilik lahan secara sepihak akan mengurangi bagian dari petani penggarap lahan garam.

8. Problematika yang muncul selama penggarapan lahan. Berdasarkan hasil survei sebanyak $12 \%$ responden mengalami permasalahan dalam melaksanakan perjanjian. Permasalahan yang timbul antara lain adalah peralatan yang disediakan pemilik lahan kurang mencukupi dan ketidaksesuaian bagi hasil antara yang diperjanjikan dengan pada saat penyerahan. Faktor utama yang menyebabkan pemberian bagi hasil tidak sesuai dengan perjanjian adalah naik turunnya harga garam di pasar. Apabila harga garam naik, maka bagi hasil diberikan sesuai dengan persentase awal perjanjian. Namun sebaliknya, apabila harga garam sedang turun bisa jadi bagi hasil yang diterima oleh petani penggarap lahan garam lebih sedikit dari yang diperjanjikan. Hal seperti inilah yang merugikan para petani penggarap lahan garam, karena tidak diatur secara jelas dan secara tertulis mengenai kondisi naik turunnya harga garam yang mempengaruhi pola bagi hasil. Sebenarnya hal ini tidak dialami oleh semua petani penggarap penggarap lahan garam, sebagian walaupun harga turun tetap menggunakan pola bagi hasil sesuai dengan kesepakatan awal.

\section{Penutup}

Secara umum praktik perjanjian bagi hasil pertanian garam terkait rukun dan syarat, seperti aqidain yang baligh dan berakal, ijab qabul dalam akad muzāra'ah, dan permodalan oleh responden di Kabupaten Pamekasan sudah sesuai dengan hukum Islam. Adapun yang berkaitan dengan jangka waktu dalam pelaksanaan akad muzāra'ah yang tidak disepakati diawal perjanjian belum sesuai dengan ketentuan hukum Islam.

Perlindungan hukum yang kurang maksimal bagi petani penggarap lahan garam disebabkan karena perjanjian yang dibuat secara tidak tertulis dan kebiasaan tidak adanya saksi dalam pembuatan penjanjian serta tidak tegasnya batasan pelaksanaan akad. Tradisi yang dianggap wajar

\footnotetext{
45 “Undang-Undang Nomor 2 Tahun 1960 Tentang Perjanjian Bagi Hasil” (n.d.).
} 
ini harus segera diubah baik melalui sosialisasi maupun peraturan yang lebih mengikat, karena pada akhirnya problematika seperti inilah yang membuat posisi hukum petani penggarap lahan garam semakin lemah. Meskipun begitu proses perjanjian bagi hasil antara petani penggarap dan pemilik lahan garam dari beberapa aspek sudah sesuai dengan asas-asas dan ketentuan yang ada, seperti adanya proses tawar menawar dalam penentuan bagi hasil. Hal itu merupakan implementasi dari asas taswiyah atau kesetaraan.

\section{DAFTAR PUSTAKA}

Anwar, Syamsul. Hukum Perjanjian Syariah: Studi Tentang Teori Akad Dalam Fikih Muamalat. Jakarta: Rajawali, 2010.

Asnawi, M. Natsir. "Perlindungan Hukum Kontrak Dalam Perspektif Hukum Kontemporer." MasalahMasalah Hukum 46, no. 1 (2017): 55-68. https://doi.org/10.14710/mmh.46.1.2017.55-68.

Badrulzaman, Mariam Darus. Aneka Hukum Bisnis. Bandung: Alumni Press, 1994.

Basri, Abdul. “4 Kabupaten Di Madura Masuk Daerah Termiskin.” Radar Madura, 2017. https:// radarmadura.jawapos.com/read/2017/07/18/1869/4-kabupaten-di-madura-masuk-daerahtermiskin.

BPS Kabupaten, and Pamekasan. "Banyaknya Penambang Garam Dan Luas Areal Pertambangan Garam Rakyat Menurut Kecamatan Di Kabupaten Pamekasan." Badan Pusat Statistik Kabupaten Pamekasan, 2015. https://pamekasankab.bps.go.id/statictable/2017/06/14/246/banyaknyapenambang-garam-dan-luas-areal-pertambangan-garam-rakyat-menurut-kecamatan-dikabupaten-pamekasan-2015.html.

Dahlan, Abdul Azis. et.al. Ensiklopedi Hukum Islam. Jakarta: Ichtiar Baru Van Hoeve, 2006.

Djamil, Fathurrahman. Penerapan Hukum Perjanjian Dalam Transaski Di Lembaga Keuangan Syariah. Jakarta: Sinar Grafika, 2012.

Fau, Teodora Nirmala \& Rafael Sebayang \& Rikando Somba. "Madura Tak Rasakan Legit Kristal Garam.” validnews.id, 2017. https://www.validnews.id/Madura-Tak-Rasakan-Legit-KristalGaram-V0000335.

Hadjon, Philipus M. Perlindungan Bagi Rakyat Di Indonesia. Surabaya: Bina Ilmu, 1987.

Hasan, M. Ali. Berbagai Macam Transaksi Dalam Islam: Fiqih Muamalah. Jakarta: Raja Grafindo Persada, 2004.

Hernoko, Agus Yudha. Hukum Perjanjian Asas Proporsionalitas Dalam Kontrak Komersial. Jakarta: Kencana Prenada Media Group, 2010.

Kansil, C.S.T. Pengantar Ilmu Hukum Dan Tata Hukum Indonesia. Jakarta: Balai Pustaka, 1989.

Mahkamah Agung Republik Indonesia. Kompilasi Hukum Ekonomi Syariah (2008).

Negara Republik Indonesia. UU Nomor 7 Tahun 2016 Tentang Perlindungan dan Pemberdayaan Nelayan, Pembudidaya Ikan dan Petambak Garam (2016).

Prodjodikoro, R. Wirjono. Asas-Asas Hukum Perjanjian. Bandung: Mandar Maju, 2011.

Putra, Gemawan Dwi. "Pulau Madura: Pulau Garam Indonesia." Indonesiabaik.id, 2018. http:// indonesiabaik.id/infografis/pulau-madura-pulau-garam-indonesia. 
Qardhawi, Yusuf. Halal Dan Haram Dalam Islam. Edited by Tim Kuadran. Bandung: Jabal Press, 2007. Raharjo, Satjipto. Ilmu Hukum. Bandung: Citra Aditya Bakti, 2015.

Satrio, J. Hukum Perikatan: Perikatan Yang Lahir Dari Perjanjian. Bandung: Citra Aditya Bakti, 1955.

Sekretariat Daerah Kabupaten Pamekasan. "Pemetaan Potensi Garam Kabupaten Pamekasan." Sekdakab Pamekasan, 2015.

Subekti, R \& R. Tjitrosudibio. Kitab Undang-Undang Hukum Perdata. Jakarta: Pradnya Paramita, 2003.

Suhendi, Hendi. Fiqih Muamalah. Jakarta: Raja Grafindo Persada, 2006.

Syamsi, Achmad Badarus. "Transformasi Hukum Ekonomi Islam Sebagai Ius Constituendum Menjadi Ius Constitutum.” Et-Tijarie: Jurnal Hukum Dan Bisnis Syariah 4, no. 1 (2017).

Triana, Nita. "Menggagas Hak Kekayaan Intelektual Perspektif Hukum Islam Ke Dalam Hukum Nasional.” Al-Manahij: Jurnal Kajian Hukum Islam 12, no. 2 (2018): 177-92.

Zuhaily, Wahbah al-. Al-Figh Al-Islam Wa Adillatuh. Edited by Abdul Hayyie al-Kattani. Jakarta: Gema Insani Press, 2011. 